\title{
Characteristics and sources of carbonaceous aerosols from Shanghai, China
}

\author{
J.-J. Cao ${ }^{1,2}$, C.-S. Zhu ${ }^{1}$, X.-X. Tie ${ }^{1,3}$, F.-H. Geng ${ }^{4}$, H.-M. Xu' ${ }^{1}$, S. S. H. Ho ${ }^{1}$, G.-H. Wang ${ }^{1}$, Y.-M. Han ${ }^{1}$, and K.-F. Ho \\ ${ }^{1}$ Key Lab of Aerosol Science \& Technology, SKLLQG, Institute of Earth Environment, Chinese Academy of Sciences, Xi' an, \\ China \\ ${ }^{2}$ Institute of Global Environmental Change, Xi' an Jiaotong University, Xi' an, China \\ ${ }^{3}$ National Center for Atmospheric Research, Boulder, CO, USA \\ ${ }^{4}$ Shanghai Meteorological Bureau, Shanghai, China \\ ${ }^{5}$ School of Public Health and Primary Care, The Chinese University of Hong Kong, Hong Kong, China
}

Correspondence to: J.-J. Cao (cao@loess.llqg.ac.cn)

Received: 12 April 2012 - Published in Atmos. Chem. Phys. Discuss.: 6 July 2012

Revised: 14 November 2012 - Accepted: 15 December 2012 - Published: 22 January 2013

\begin{abstract}
An intensive investigation of carbonaceous $\mathrm{PM}_{2.5}$ and TSP (total suspended particles) from Pudong (China) was conducted as part of the MIRAGE-Shanghai (Megacities Impact on Regional and Global Environment) experiment in 2009. Data for organic and elemental carbon (OC and EC), organic species, including $\mathrm{C} 17$ to $\mathrm{C} 40 n$-alkanes and 17 polycyclic aromatic hydrocarbons (PAHs), and stable carbon isotopes $\mathrm{OC}\left(\delta^{13} \mathrm{C}_{\mathrm{OC}}\right)$ and $\mathrm{EC}\left(\delta^{13} \mathrm{C}_{\mathrm{EC}}\right)$ were used to evaluate the aerosols' temporal variations and identify presumptive sources. High OC/EC ratios indicated a large fraction of secondary organic aerosol (SOA); high char/soot ratios indicated stronger contributions to EC from motor vehicles and coal combustion than biomass burning. Diagnostic ratios of PAHs indicated that much of the SOA was produced via coal combustion. Isotope abundances $\left(\delta^{13} \mathrm{C}_{\mathrm{OC}}=-24.5 \pm 0.8 \%\right.$ o and $\delta^{13} \mathrm{C}_{\mathrm{EC}}=-25.1 \pm 0.6 \%$ ) indicated that fossil fuels were the most important source for carbonaceous $\mathrm{PM}_{2.5}$ (particulate matter less than 2.5 micrometers in diameter), with lesser impacts from biomass burning and natural sources. An EC tracer system and isotope mass balance calculations showed that the relative contributions to total carbon from coal combustion, motor vehicle exhaust, and SOA were $41 \%, 21 \%$, and $31 \%$; other primary sources such as marine, soil and biogenic emissions contributed $7 \%$. Combined analyses of OC and EC, $n$-alkanes and PAHs, and stable carbon isotopes provide a new way to apportion the sources of carbonaceous particles.
\end{abstract}

\section{Introduction}

The urbanization of China, coupled with rapid industrial development, has led to serious air pollution problems in many of the country's large cities. Among the aerosol pollutants, carbonaceous particles have been the focus of growing attention owing to their importance for environmental pollution and their effects on climate, and human health (Charlson et al., 1992; Arimoto et al., 1996; IPCC, 2007; Ye et al., 2003; Zhang et al., 2007; Zhang et al., 2009; Ramana et al., 2010). Previous studies have shown that in many Chinese cities carbonaceous pollutants account for 20 to $50 \%$ of mass of particulate matter less than 2.5 micrometers in diameter $\left(\mathrm{PM}_{2.5}\right)$ (He et al., 2001; Cao et al., 2004, 2005, 2007; Shen et al., 2007, 2009). Further, much of the recent research on atmospheric $n$-alkanes and polycyclic aromatic hydrocarbons (PAHs), which are major components of the carbonaceous aerosol, has focused on urban environments (Seinfeld and Pankow, 2003; He et al., 2006; Hou et al., 2006). Information on the types and loadings of carbonaceous aerosol components is needed to determine the severity of urban air pollution, implement effective control measures, and develop future strategies for urban air quality improvement (Dockery et al., 1993; Turpin et al., 2000; Jacobson et al., 2000; Mauderly and Chow, 2008).

Shanghai is an economic hub, as well as a center for science and technology, in eastern China; and it is also a major industrial base, being home to the largest petrochemical

Published by Copernicus Publications on behalf of the European Geosciences Union. 
complex in China and other major industries. Rapid economic growth and urbanization in China have sharply increased the quantities of fossil fuels burned for energy production, and this has led to serious air pollution and other related problems (Ye et al., 2003). Previous studies have shown that organic compounds and sulfate are often the most abundant aerosol components, but these substances differ in massparticle size distributions, being concentrated in the fine and coarse modes, respectively (Yao et al., 2002; Ye et al., 2003; Yang et al., 2005; Feng et al., 2009).

Here, we present data for carbonaceous aerosols, which were produced as part of an exploratory campaign called the Megacity Impacts on Regional and Global Environments (MIRAGE-Shanghai 2009, http://www.acd.ucar.edu/mirage). This project was conducted in collaboration with the Shanghai Meteorological Bureau. The goal of the campaign was to assess the concentrations of pollutants and their chemical precursors in preparation for more detailed fieldwork in the future. The broad objective of our specific component of this campaign was to obtain information on the chemical composition of carbonaceous aerosols, and the sources for these particles at the Pudong site in Shanghai. Data for selected atmospheric carbon fractions, including organic carbon (OC), elemental carbon (EC), char and soot fractions in the EC aerosol, $n$-alkanes and PAHs, and stable carbon isotopes in OC and EC, were obtained for this purpose. Specific objectives for our study were: (1) to document the variations of selected carbonaceous species during the MIRAGE-Shanghai 2009 Experiment; (2) to use diagnostic ratios for source identification; and (3) to quantitatively estimate the source contributions for carbonaceous aerosols.

\section{Experimental}

\subsection{Sampling}

Shanghai is the largest city by population in China, and it represents an important anthropogenically impacted coastal environment in eastern China. Aerosol sampling was conducted at a site in Shanghai called Pudong (see Fig. 1 in Friedli et al., 2011) from 1 to 20 September 2009. Total suspended particle (TSP) and $\mathrm{PM}_{2.5}$ samples were collected on separate quartz filters using two Mini-Volume samplers (Airmetrics, Oregon, USA) that operated in parallel during the day (08:00 to 20:00 local time) and again at night (20:00 to 08:00). The flow rate for these samplers was $51 \mathrm{~min}^{-1}$. Additionally, Hi-vol samples were collected for isotope studies using a Tisch Hi-vol $\mathrm{PM}_{2.5}$ sampler (TE-6001, Tisch Environmental, Village of Cleves, Ohio, USA) over a period of $24 \mathrm{~h}$ at a flow rate of $10001 \mathrm{~min}^{-1}$. Meteorological data (wind speed and wind direction) also were collected during the sampling period.

\subsection{Chemical analyses}

\subsubsection{Carbonaceous aerosol analyses}

The carbonaceous aerosol consists of two fractions in the urban atmosphere: the first is produced as primary emissions, and the other results from the formation of the secondary organic aerosol (SOA) through various chemical processes. Primary emissions are the only source for EC, and major sources for EC include coal combustion, motor vehicle exhaust, and biomass burning. Unlike EC, OC can either be formed directly by physical processes (primary OC or POC) or from precursor gases (secondary OC or SOC). Major sources for OC include biomass burning, fossil fuels, and natural sources, especially vegetation and soils (Cao et al., 2005; Duan et al., 2006; Friedli et al., 2011).

Carbon analyses were carried out with the use of a Desert Research Institute (DRI) Model 2001 carbon analyzer (Atmoslytic Inc., Calabasas, CA, USA). The IMPROVE-A thermal/optical reflectance (TOR) protocol (Chow et al., 1993, 2004) was used for these analyses. A punch aliquot of a quartz filter sample was heated in a stepwise manner to obtain data for four OC fractions (OC1, OC2, OC 3 , and $\mathrm{OC} 4$ in a helium atmosphere at $140^{\circ}, 280^{\circ}, 480^{\circ}$, and $580^{\circ} \mathrm{C}$ ), and three $\mathrm{EC}$ fractions (EC1, EC2, and EC3 in a $2 \%$ oxygen $/ 98 \%$ helium atmosphere at $580^{\circ}, 740^{\circ}$, and $840^{\circ} \mathrm{C}$ ). At the same time, OP (pyrolized carbon) was produced at $<580^{\circ} \mathrm{C}$ in the inert atmosphere, this component decreases the reflected light to correct for charred OC. The EC fraction was further divided into char and soot (Han et al., 2007, 2009). Total OC is defined as the sum of the four OC fractions plus OP, and total EC is the sum of the three EC fractions minus OP. Specific quality assurance/quality control (QA/QC) procedures for these analyses have been described in detail in Cao et al. (2003).

\subsubsection{Char and soot analyses}

Previous studies have shown that char and soot fractions of EC have different chemical, physical and light absorbing properties (Kuhlbusch, 1997; Masiello, 2004; Reid et al., 2005). Char is produced via the heating of organic substances, and it can be formed directly from pyrolysis, or it can occur as an impure form of graphitic carbon when carbonaceous material is partially burned or heated in a limited volume of air. Soot is defined as the fraction of carbon particles that form at high temperature through gas-phase processes. Recognizing these functional differences in the two EC fractions, we used a thermal optical reflectance method (Han et al., 2009) to determine the concentrations of char and soot. Char is defined as EC1 minus OP, while soot is defined as the sum of EC2 and EC3. 


\subsubsection{Stable carbon isotope analyses}

The particulate carbon captured on the quartz filters was oxidized to $\mathrm{CO}_{2}$ by heating the filters to $375^{\circ} \mathrm{C}$ (under vacuum) for $3 \mathrm{~h}$ in the presence of $\mathrm{CuO}$ catalyst grains, followed by combustion at $850^{\circ} \mathrm{C}$ for $5 \mathrm{~h}$. The $\mathrm{CO}_{2}$ was isolated through a series of cold traps, and $\delta^{13} \mathrm{C}$ was determined from the carbon dioxide $\left(\mathrm{CO}_{2}\right)$ that evolved in two stages using a Finnigan MAT-251 ratio mass spectrometer (Thermo Electron Corporation, Burlington, Ontario, Canada). The stable carbon isotopic composition of the $\mathrm{CO}_{2}$ combusted at $375^{\circ} \mathrm{C}$ was determined as $\delta^{13} \mathrm{C}$ OC and that at $850{ }^{\circ} \mathrm{C}$ was $\delta^{13} \mathrm{C}_{\mathrm{EC}}$ (Ho et al., 2006; Cao et al., 2011). Detailed quality assurance/quality control (QA/QC) procedures for stable $\mathrm{C}$ isotopes analyses have been described in detail elsewhere (Ho, 2006; Cao et al., 2011). $\delta^{13} \mathrm{C}$ values, based on the international standard PDB (a limestone called Pee Dee Belemnite - or PDB) from South Carolina, were calculated as follows,

$\delta^{13} \mathrm{C}=\left({ }^{13} \mathrm{C} /{ }^{12} \mathrm{C}_{\text {sample }} /{ }^{13} \mathrm{C} /{ }^{12} \mathrm{C}_{\text {standard }}-1\right) \times 1000$.

\subsection{4 n-alkanes and PAHs analyses}

Traditional methods for determining $n$-alkanes and PAHs involve solvent extraction (SE) followed by gas chromatography/mass spectrometry (GC/MS) (USEPA Method TO-13A, 1997; Santos and Galceran, 2003). For our study, we used an in-injection port thermal desorption GC/MS method because it involves a short sample preparation time $(<1 \mathrm{~min})$; but more important, the procedure minimizes contamination from solvent impurities, and detection limits as low as a few nanograms of the target analytes can be achieved (Cass, 1998; Ho and Yu, 2004; Chow et al., 2007; Bi et al., 2008; van Drooge et al., 2009; Ho et al., 2008, 2011).

Aliquots were cut from the filters (areas of $1.0 \mathrm{~cm}^{2}$ to $3.2 \mathrm{~cm}^{2}$, depending on the aerosol loading in each sample) with the use of a stainless steel punch and a pre-baked glass sheet, and they were then loaded into thermal desorption (TD) glass tubes. A small amount of pre-baked silane-treated glass wool (Sigma-Aldrich, Bellefonte, PA, USA) was inserted at each end of the tube to prevent the filter from sliding out and large particles from entering the column. The loaded glass tubes were stored inside capped test tubes and were kept in a desiccator before analysis.

Calibration standards were prepared by spiking known amounts of $n$-alkane and PAH liquid standard mixtures (Sigma-Aldrich, Bellefonte, PA, USA) onto pre-baked $\left(780^{\circ} \mathrm{C}\right.$ for at least $\left.4 \mathrm{~h}\right)$ quartz-fiber filters $\left(1.0 \mathrm{~cm}^{2}\right)$. Calibration curves were constructed by plotting the peak areas versus the amount of each species in the standards. Moreover, two deuterated compounds, $n$-tetracosane-d50 (n-C24D50) (98\%, Aldrich, Milwaukee, WI, USA) and phenanthrened10 (phed10) (98\%, Aldrich), were used as internal standards (IS) for the analyses.

In this study, the GC oven program was initially held at $30^{\circ} \mathrm{C}$ for $2 \mathrm{~min}$, ramped at $12^{\circ} \mathrm{C} \mathrm{min}^{-1}$ to $120^{\circ} \mathrm{C}$, ramped at $8{ }^{\circ} \mathrm{C} \mathrm{min}{ }^{-1}$ to $280{ }^{\circ} \mathrm{C}$, then ramped at $12{ }^{\circ} \mathrm{Cmin}^{-1}$ to $325^{\circ} \mathrm{C}$, and held at $325^{\circ} \mathrm{C}$ for $20 \mathrm{~min}$ until the end of the analysis. The quadrupole mass spectrometer was operated in the electric impact mode at $70 \mathrm{eV}$. The mass selective detector was scanned from 50 to $550 \mathrm{amu}$. The GC was equipped with an HP-5MS (5\% diphenyl/95\% dimethylsiloxane, $30 \mathrm{~m} \times 0.25 \mathrm{~mm} \times 0.25 \mu \mathrm{m})$ capillary column $(\mathrm{Ag}-$ ilent Technologies, Inc. Santa Clara, CA, USA), and ultra high purity helium $(99.9999 \%$ at a constant pressure of 8.4 psi and flow of $1.0 \mathrm{ml} \mathrm{min}^{-1}$ ) was used as the carrier gas.

We determined the concentrations of $24 n$-alkanes (C17 to $\mathrm{C} 40$ ) and 17 PAHs, including phenanthrene (PHE), anthracene (ANT), fluoranthene (FLU), pyrene (PYR), benzo[a]anthracene (BaA), chrysene (CHR), benzo[b]fluoranthene $(\mathrm{BbF})$, benzo[k]fluoranthene $(\mathrm{BkF})$ benzo[a]fluoranthene (BaF), benzo[e]pyrene (BeP), benzo[a]pyrene (BaP), perylene (PER), indeno[1,2,3cd]pyrene (IcdP), dibenzo[a,h]anthracene (DahA), benzo[ghi] perylene (BghiP), coronene (COR), and dibenzo[a,e]pyrene (DaeP). $n$-alkanes were quantified by the ions at $m / z 57$ except for $\mathrm{C}_{19}$ (which was determined using the molecular ion: $m / z$ 268). PAHs were quantified by their respective molecular ions. Identification was achieved by comparing the mass spectra and retention times of the chromatographic peaks with those of authentic standards.

National Institute of Standards and Technology (NIST) Standard Reference Material (SRM) 1649b was employed to validate the accuracy of PAH analyses. The relative error between the certified values in SRM 1649b and the calibration standard concentrations was $<9.6 \%$, demonstrating the reliability and accuracy of PAHs concentrations measured by our TD-GC/MS method. The limit of detection (LOD) of the method was defined as the minimum amount of an $n$-alkane or a PAH that generated the minimum detectable signal plus three times the standard deviation of the blank signals. No peaks were detected for either the $n$-alkanes or PAHs in the blank calibration samples. As a result, we approximated the mean blank signal with the calibration line intercept and the blank signal standard deviation with the standard error for the $y$ (peak area) estimate.

Using this approach, the LODs in nanograms per sample were calculated to be in the range of 0.016 to $0.075 \mathrm{ng}$ for $n$-alkanes and 0.025 to $0.560 \mathrm{ng}$ for PAHs (Table 1). Replicate analyses were conducted on every $10 \mathrm{TH}$ sample. The relative standard deviations (RSDs) for the samples were 1.5 to $9.3 \%$ for the target compounds. The good reproducibility demonstrates the quantitative desorption of the non-polar compounds from the filter as well as the stability of the MS system. 
Table 1. Limits of detection (LODs) for the measured species in this study.

\begin{tabular}{lllll}
\hline$n$-alkane (abbreviation) & LOD $(\mathrm{ng})$ & PAH (abbreviation) & Rings & LOD (ng) \\
\hline heptadecane $\left(\mathrm{C}_{17}\right)$ & 0.063 & phenanthrene (PHE) & 3 & 0.165 \\
octadecane $\left(\mathrm{C}_{18}\right)$ & 0.055 & anthracene (ANT) & 3 & 0.115 \\
nonadecane $\left(\mathrm{C}_{19}\right)$ & 0.075 & fluoranthene (FLU) & 4 & 0.061 \\
icosane $\left(\mathrm{C}_{20}\right)$ & 0.074 & pyrene (PYR) & 4 & 0.073 \\
heneicosane $\left(\mathrm{C}_{21}\right)$ & 0.073 & benzo[a]anthracene (BaA) & 4 & 0.025 \\
docosane $\left(\mathrm{C}_{22}\right)$ & 0.081 & chrysene (CHRY) & 4 & 0.041 \\
tricosane $\left(\mathrm{C}_{23}\right)$ & 0.052 & benzo[b]fluoranthene (BbF) & 5 & 0.063 \\
tetracosane $\left(\mathrm{C}_{24}\right)$ & 0.038 & benzo[k]fluoranthene (BkF) & 5 & 0.055 \\
pentacosane $\left(\mathrm{C}_{25}\right)$ & 0.033 & benzo[a]fluoranthene (BaF) & 5 & 0.059 \\
hexacosane $\left(\mathrm{C}_{26}\right)$ & 0.037 & benzo[e]pyrene (BeP) & 5 & 0.026 \\
heptacosane $\left(\mathrm{C}_{27}\right)$ & 0.032 & benzo[a]pyrene (BaP) & 5 & 0.026 \\
octacosane $\left(\mathrm{C}_{28}\right)$ & 0.023 & perylene (PER) & 5 & 0.026 \\
nonacosane $\left(\mathrm{C}_{29}\right)$ & 0.021 & indeno[1,2,3-cd]pyrene (IcdP) & 6 & 0.036 \\
triacontane $\left(\mathrm{C}_{30}\right)$ & 0.018 & dibenzo[a,h]anthracene (DahA) & 5 & 0.034 \\
hentriacotane $\left(\mathrm{C}_{31}\right)$ & 0.016 & benzo[ghi] perylene (BghiP) & 6 & 0.066 \\
dotriacontane $\left(\mathrm{C}_{32}\right)$ & 0.023 & coronene (COR) & 7 & 0.165 \\
tritriactotane $\left(\mathrm{C}_{33}\right)$ & 0.025 & dibenzo[a,e]pyrene (DaeP) & 6 & 0.560 \\
tetratriactoane $\left(\mathrm{C}_{34}\right)$ & 0.034 & & & \\
pentatriacontane $\left(\mathrm{C}_{35}\right)$ & 0.032 & & & \\
hexatriacontane $\left(\mathrm{C}_{36}\right)$ & 0.035 & & & \\
heptatriacontane $\left(\mathrm{C}_{37}\right)$ & 0.039 & & & \\
octatriacontane $\left(\mathrm{C}_{38}\right)$ & 0.026 & & & \\
nonatriacontane $\left(\mathrm{C}_{39}\right)$ & 0.033 & & & \\
tetracontane $\left(\mathrm{C}_{40}\right)$ & 0.046 & & & \\
\hline
\end{tabular}

\section{Results and discussion}

\subsection{Variations of $\mathrm{OC}$, EC, char, soot, and eight carbon fractions}

The 12-h average concentrations of OC and EC during the sampling period were 6.8 and $1.8 \mu \mathrm{g} \mathrm{m}^{-3}$ in $\mathrm{PM}_{2.5}$ and 10.1 and $2.5 \mu \mathrm{g} \mathrm{m}^{-3}$ in TSP, respectively (Table 2). The $\mathrm{PM}_{2.5} \mathrm{OC}$ and EC concentrations plotted in Fig. 1 show that $\mathrm{OC}$ varied from $2.8 \mu \mathrm{g} \mathrm{m}^{-3}$ during the night of 4 September 2009 to $14.6 \mu \mathrm{g} \mathrm{m}^{-3}$ in the day on 15 September. In comparison, EC concentrations were much lower, ranging from $0.9 \mu \mathrm{g} \mathrm{m}^{-3}$ on the night of 2 September to $3.9 \mu \mathrm{g} \mathrm{m}^{-3}$ in the day on 12 September (Fig. 1). The maximum-to-minimum concentration ratios for $\mathrm{OC}$ and $\mathrm{EC}$ were 5.1 and 4.2, respectively. The greater variability for $\mathrm{OC}$ is presumably due to more complex sources for this carbon fraction, most especially those leading to the formation of SOA. Figure 1 also shows that the temporal variability of OC was decoupled from that of $\mathrm{EC}$, and this more than likely reflects the complex mixtures of sources that contributed to the carbonaceous aerosol loadings.

The average day-to-night ratios $(\mathrm{D} / \mathrm{N})$ for OC and $\mathrm{EC}$ were 1.4 and 1.1 , respectively (Table 3 ), and the difference between these D/N ratios is another indication that $\mathrm{OC}$ and $\mathrm{EC}$ originated from different sources. The higher $\mathrm{D} / \mathrm{N}$ ratio for OC may be ascribed to the formation of SOA and to stronger
Table 2. Concentrations of PM mass, OC, EC, char, soot in $\mathrm{PM}_{2.5}$ and TSP (units: $\mu \mathrm{g} \mathrm{m}^{-3}$ ).

\begin{tabular}{lllll}
\hline \multirow{2}{*}{ Analyte } & \multicolumn{2}{c}{$\mathrm{PM}_{2.5}$} & \multicolumn{2}{c}{ TSP } \\
\cline { 2 - 5 } & Average & Range & Average & Range \\
\hline PM mass & 40.3 & $19.9-99.9$ & 81.4 & $36.4-176.0$ \\
OC & 6.79 & $2.84-14.58$ & 10.11 & $2.86-20.19$ \\
EC & 1.76 & $0.93-3.86$ & 2.45 & $1.00-4.93$ \\
Char & 1.11 & $0.25-2.96$ & 1.72 & $0.42-4.15$ \\
Soot & 0.65 & $0.19-1.42$ & 0.73 & $0.22-2.17$ \\
\hline
\end{tabular}

non-combustion emissions during the day. The $\mathrm{D} / \mathrm{N}$ ratio for EC was close to unity, indicating relatively comparable combustion emissions when averaged over the day- and nighttime sampling intervals. The concentrations of OC and EC in $\mathrm{PM}_{2.5}$ were similar to those reported for previous studies at Shanghai (Ye et al., 2003; Feng et al., 2006a), and they also were comparable to those measured at other Chinese megacities, including Beijing and Guangzhou (Cao et al., 2007).

Both char and soot were predominantly in the $\mathrm{PM}_{2.5}$ fraction: char averaged $1.1 \mu \mathrm{g} \mathrm{m}^{-3}$ in $\mathrm{PM}_{2.5}$ versus $1.7 \mu \mathrm{g} \mathrm{m}^{-3}$ in TSP while the corresponding values for soot were $0.65 \mu \mathrm{g} \mathrm{m}^{-3}$ in $\mathrm{PM}_{2.5}$ and $0.73 \mu \mathrm{g} \mathrm{m}^{-3}$ in TSP. Char varied from $0.3 \mu \mathrm{g} \mathrm{m}^{-3}$ on 5 September (day) to $3 \mu \mathrm{g} \mathrm{m}^{-3}$ on 12 September (day). Soot ranged from a low of $0.2 \mu \mathrm{g} \mathrm{m}^{-3}$ on 
Table 3. Day/night $(\mathrm{D} / \mathrm{N})$ ratios and their standard deviations for the concentrations of PM mass, OC, EC, char, and soot in PM 2.5 and TSP.

\begin{tabular}{llllll}
\hline D/N ratio & PM mass & OC & EC & Char & Soot \\
\hline $\mathrm{PM}_{2.5}$ & $1.38 \pm 0.45$ & $1.41 \pm 0.63$ & $1.13 \pm 0.44$ & $1.14 \pm 0.68$ & $1.33 \pm 0.81$ \\
TSP & $1.34 \pm 0.46$ & $1.57 \pm 1.15$ & $1.15 \pm 0.55$ & $1.33 \pm 1.05$ & $1.40 \pm 0.98$ \\
\hline
\end{tabular}

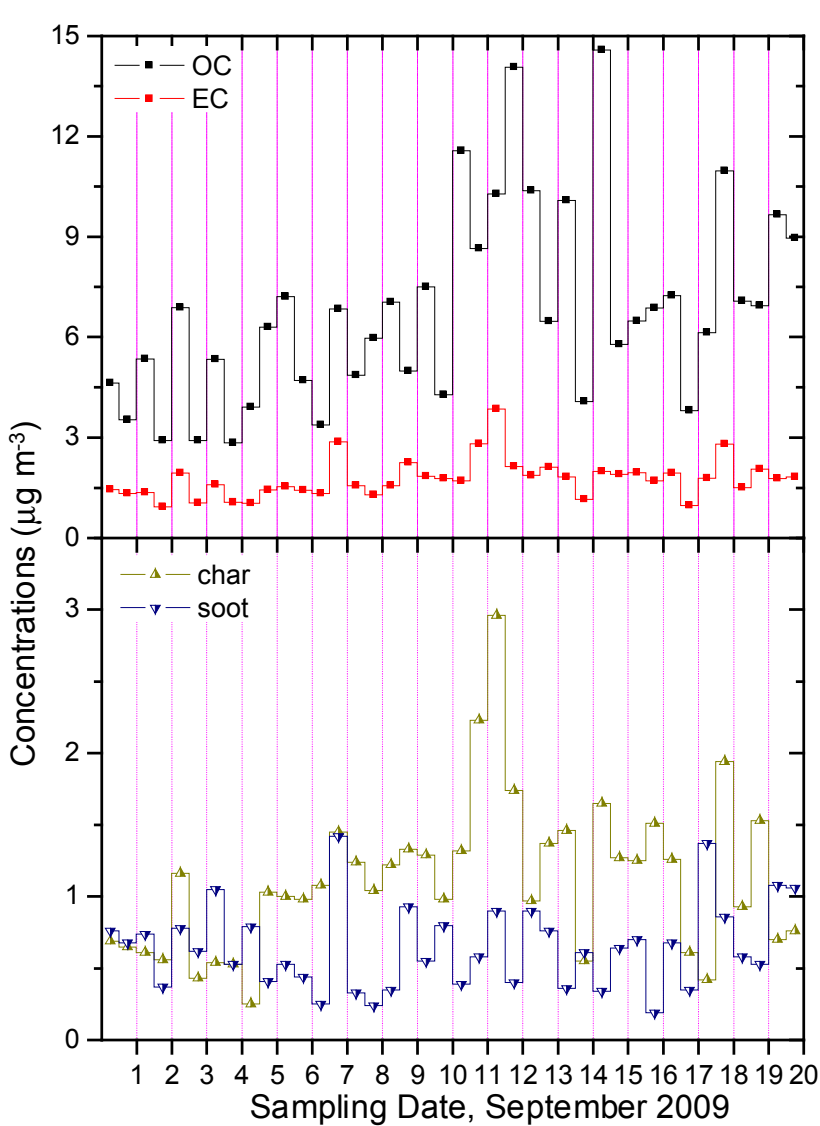

Fig. 1. Time series of OC, EC, char and soot for $\mathrm{PM}_{2.5}$ in daytime and nighttime.

16 September (night) to a high of $1.4 \mu \mathrm{g} \mathrm{m}^{-3}$ on 7 September (night, Fig. 1). The concentrations of char and soot in $\mathrm{PM}_{2.5}$ were similar to those reported for a previous study in Shanghai (char in summer: $1.8 \mu \mathrm{g} \mathrm{m}^{-3}$, soot in summer: $1.1 \mathrm{~g} \mathrm{~m}^{-3}$; Han et al., 2009) and Saitama, a city in Japan (char in summer: $1.85 \mu \mathrm{g} \mathrm{m}^{-3}$, soot: $0.47 \mu \mathrm{g} \mathrm{m}^{-3}$; Kim et al., 2011a).

The maximum-to-minimum ratios for char and soot were 11.8 and 7.5, respectively. The higher variability for char and soot, compared with OC and EC, may be explained by the relatively widespread combustion sources for EC and the dilution of char and soot that can occur during the day or at night. Furthermore, the temporal pattern exhibited by char (Fig. 1) was decoupled from that of soot, and this can most easily be explained by differences in the primary emission sources for the char versus soot particles. A slightly higher

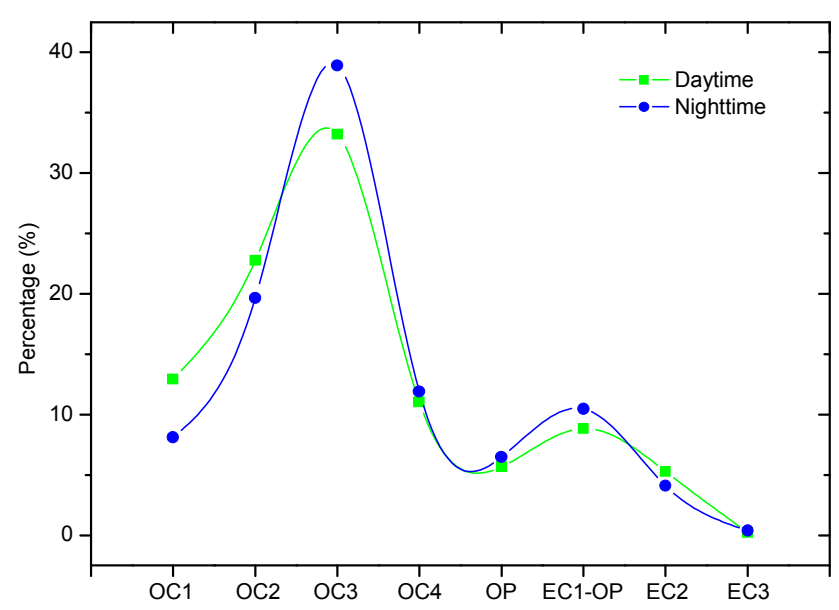

Fig. 2. Average percentage of total carbon contributed by eight carbon fractions in $\mathrm{PM}_{2.5}$.

average $\mathrm{D} / \mathrm{N}$ ratio was found for soot (1.3) compared with char (1.1, Table 3), and this implies that the emissions of primary soot particles, possibly from motor vehicles, were somewhat greater during the daytime.

One of the important features of the IMPROVE TOR protocol is that the system's temperature does not advance from one setting to the next until a well-defined carbon peak has evolved (Chow et al., 1993, 2004). Carbon abundances in each of these fractions differ as a function of the source contributions (Chow et al., 2003; Cao et al., 2004, 2005; Zhu et al., 2010). The average percentages for eight carbon fractions in daytime and nighttime $\mathrm{PM}_{2.5}$ are shown in Fig. 2. The average abundances of OC1, OC2, OC3, OC4, OP, EC1-OP, $\mathrm{EC} 2$, and EC3 during the day were $13 \%, 23 \%, 33 \%, 11 \%$, $6 \%, 9 \%, 5 \%$, and $0.2 \%$, respectively. The corresponding percentages for the nighttime samples paralleled those during the day, implying the major contributing sources, especially coal combustion and motor vehicle exhaust, were similar for carbonaceous aerosols throughout the day and night.

Closer inspection of the data shows that OC1 (volatile OC) and OC2 concentrations during the day (OC1: $13 \%$, OC2: $23 \%$ ) were slightly higher than those during the night (OC1: $8 \%$, OC2: 20\%). This may be explained by stronger emissions from biogenic sources and gasoline-powered vehicle exhaust during the day. OC3 (high temperature organic carbon) during the night was $\sim 39 \%$, which was higher than that $(33 \%)$ during daytime. The carbon profiles were characterized by two peaks, the highest was OC3 and the 


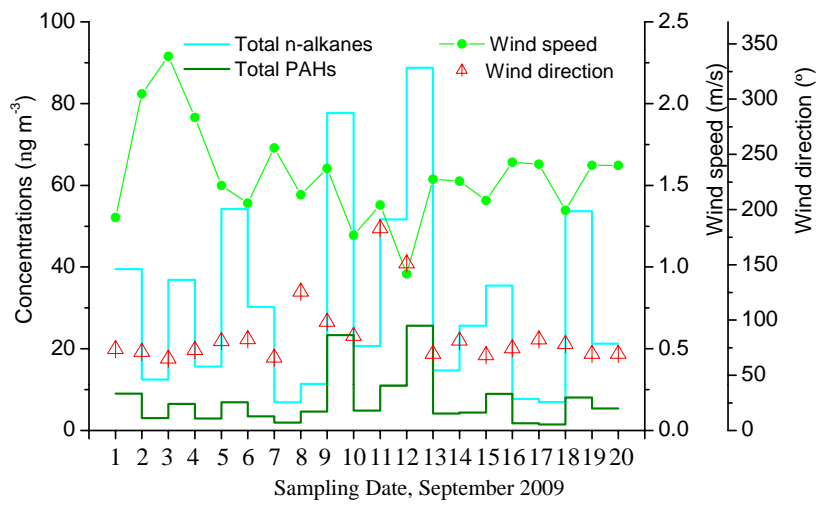

Fig. 3. Influence of meteorology conditions (wind speed and wind direction) on $n$-alkanes and PAHs concentrations.

second highest EC1-OP; this is similar to the carbon profile reported for Nanchang during the summer of 2009 (Huang et al., 2011). On the other hand, the carbon profiles at Shanghai differ from those at four cities in the Pearl River Delta (Cao et al., 2004), Xi' an (Cao et al., 2005), Taiwan (Xueshan Tunnel, Zhu et al., 2010), and Saitama City, Japan (Kim et al., 2011b), and these differences are a reflection of the diversity in carbonaceous aerosol sources throughout Asia.

\subsection{Characteristics of $\boldsymbol{n}$-alkanes and PAHs}

The concentrations of the $\mathrm{C} 17$ to $\mathrm{C} 40 n$-alkanes in $\mathrm{PM}_{2.5}$ are summarized in Table 4. The 24-h average concentration of the sum of the measured $n$-alkanes was $32.2 \mathrm{ng} \mathrm{m}^{-3}$, and the range was from $6.9 \mathrm{ng} \mathrm{m}^{-3}$ on 17 September to $88.8 \mathrm{ng} \mathrm{m}^{-3}$ on 12 September. The highest daily concentration of total $n$-alkanes, OC $\left(12.2 \mu \mathrm{g} \mathrm{m}^{-3}\right)$, EC $\left(3.0 \mu \mathrm{g} \mathrm{m}^{-3}\right)$, and char $\left(2.4 \mu \mathrm{g} \mathrm{m}^{-3}\right)$ all occurred on 12 September (Fig. 1). Inspection of wind direction data showed that the carbonaceous aerosol plume, associated with this serious pollution episode, was most likely transported to the sampling site from the southeast (Fig. 3). The total $n$-alkanes in this study were lower than those measured at Shanghai in winter (ranging 32.9 to $314.9 \mathrm{ng} \mathrm{m}^{-3}$; average $149.5 \mathrm{ng} \mathrm{m}^{-3}$ ), but higher than in summer (ranging 12.2 to $39.2 \mathrm{ng} \mathrm{m}^{-3}$; average $22.5 \mathrm{ng} \mathrm{m}^{-3}$, Feng et al., 2006a). Further comparisons show that the total $n$-alkane concentrations in Shanghai ranked among the lower levels previously measured in 14 Chinese cities (Wang et al., 2006; the ensemble annual average concentration for these cities was $340 \mathrm{ng} \mathrm{m}^{-3}$ ). In addition, the $n$-alkane concentrations in Guangzhou and Beijing measured in the summer of 2003 (Feng et al., 2006b) were 2 and 6 times those we measured in Shanghai.

The $n$-alkanes detected in $\mathrm{PM}_{2.5}$ were characterized by odd carbon number preference, with a peak at C29 (average concentration $3.8 \mathrm{ng} \mathrm{m}^{-3}$ ) followed by $\mathrm{C} 27$ and $\mathrm{C} 31$ (Fig. 4a). Similar patterns have been observed in previous studies at Shanghai and in other Chinese cities, including

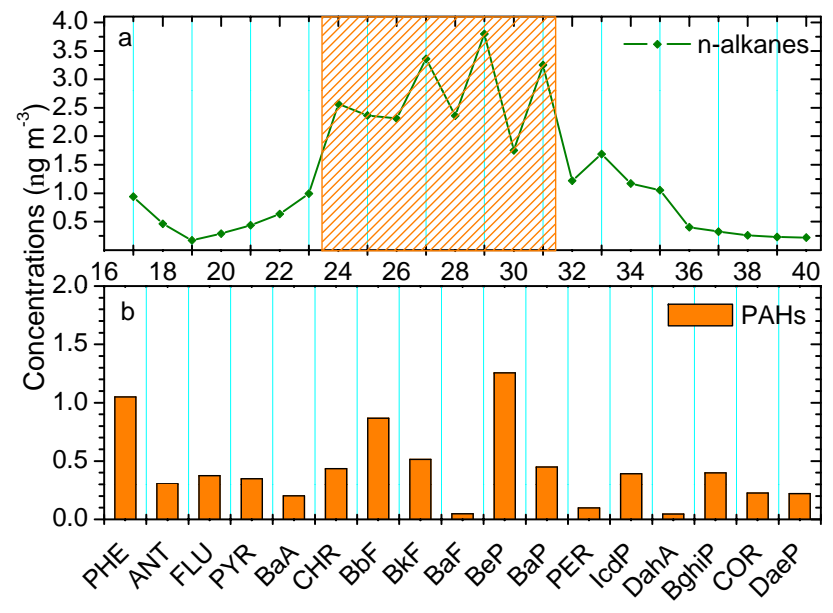

Fig. 4. The average concentrations for each $n$-alkane species (a) and each PAH species (b) in $\mathrm{PM}_{2.5}$.

Beijing and Tianjin (Feng et al., 2006a, b; He et al., 2006; Li et al., 2010). The carbon preference index (CPI), defined as concentration ratio of odd to even carbon number $n$-alkanes, is a diagnostic tool used to evaluate the relative strengths of biogenic versus anthropogenic sources. A CPI value is close to unity for anthropogenic source materials (e.g., petroleum) but around 10 for higher plant waxes (Simoneit, 1985; Sicre et al., 1987; Peltzer and Gagosian, 1989). In our study, the relatively low CPI values (1.0 to 1.7 , Table 4) indicated that there were important contributions from anthropogenic sources, including petroleum, coal combustion, diesel and gasoline engines, and so on, in Shanghai during the sampling period.

$\mathrm{C}_{\max }$ is used to denote the $n$-alkanes that exhibit the highest concentration among the $n$-alkane homologues, and this metric provides another way of assessing biogenic versus anthropogenic source strengths. Low $\mathrm{C}_{\max }$ values indicate that petroleum residues were the stronger $n$-alkane source while a high $\mathrm{C}_{\max }$ suggests more important contributions from biogenic sources (Simoneit, 1984, 1985). The $\mathrm{C}_{\max }$ in our study was nonacosane (C29), and relatively high concentrations for C24 through C33 were observed. This finding indicates that primary biogenic sources did make some contributions to the atmosphere of Shanghai, even though they were not the most important ones for the $n$-alkanes.

The pronounced temporal variations observed for PAHs were similar to those exhibited by the $n$-alkanes (Fig. 3). The average concentration for the $17 \mathrm{PAHs}$ was $7.2 \mathrm{ng} \mathrm{m}^{-3}$ (Table 4), with the lowest value $\left(1.5 \mathrm{ng} \mathrm{m}^{-3}\right)$ on 17 September and the highest $\left(25.6 \mathrm{ng} \mathrm{m}^{-3}\right)$ on 12 September. The peak concentrations of the sum of the PAHs coincided with those for total $n$-alkanes, OC, EC, and char, again demonstrating that a strong pollution event occurred on 12 September (Figs. 1 and 3). The PAH concentrations were comparable to previous results from Shanghai (Feng et al., 2006a, b) and 
Table 4. Concentrations (units: $\mathrm{ng} \mathrm{m}^{-3}$ ) and some indices of $n$-alkanes and PAHs.

\begin{tabular}{llllll}
\hline$n$-alkane & Average & Range & PAH & Average & Range \\
\hline heptadecane (n-C17) & 0.94 & $0.14-3.11$ & PHE & 1.05 & $0.22-3.40$ \\
octadecane (n-C18) & 0.46 & $0.08-1.15$ & ANT & 0.31 & $0.07-0.95$ \\
nonadecane (n-C19) & 0.17 & $0.03-0.54$ & FLU & 0.37 & $0.07-1.62$ \\
icosane (n-C20) & 0.29 & $0.06-0.72$ & PYR & 0.35 & $0.07-1.51$ \\
heneicosane (n-C21) & 0.44 & $0.09-1.07$ & BaA & 0.20 & $0.03-0.93$ \\
docosane (n-C22) & 0.64 & $0.14-1.69$ & CHR & 0.43 & $0.10-1.56$ \\
tricosane (n-C23) & 0.99 & $0.20-2.43$ & BbF & 0.87 & $0.16-3.00$ \\
tetracosane (n-C24) & 2.57 & $0.51-5.86$ & BkF & 0.51 & $0.11-1.72$ \\
pentacosane (n-C25) & 2.37 & $0.49-5.89$ & BaF & 0.05 & $0.01-0.20$ \\
hexacosane (n-C26) & 2.31 & $0.52-5.36$ & BeP & 1.26 & $0.22-4.33$ \\
heptacosane (n-C27) & 3.36 & $0.65-8.90$ & BaP & 0.45 & $0.05-2.22$ \\
octacosane (n-C28) & 2.36 & $0.46-5.75$ & PER & 0.10 & $0.01-0.48$ \\
nonacosane (n-C29) & 3.80 & $0.71-12.90$ & IcdP & 0.39 & $0.06-1.39$ \\
triacontane (n-C30) & 1.75 & $0.36-4.93$ & DahA & 0.05 & $0.01-0.21$ \\
hentriacotane (n-C31) & 3.25 & $0.64-10.67$ & BghiP & 0.40 & $0.07-1.38$ \\
dotriacontane (n-C32) & 1.22 & $0.21-3.94$ & COR & 0.22 & $0.02-0.80$ \\
tritriactotane (n-C33) & 1.69 & $0.23-5.20$ & DaeP & 0.22 & $0.01-0.96$ \\
tetratriactoane (n-C34) & 1.17 & $0.15-3.61$ & & & \\
pentatriacontane (n-C35) & 1.05 & $0.16-3.69$ & Sum & 7.23 & $1.45-25.63$ \\
hexatriacontane (n-C36) & 0.40 & $0.06-1.29$ & BeP/(BeP+BaP) & 0.76 & $0.66-0.85$ \\
heptatriacontane (n-37) & 0.32 & $0.04-1.20$ & & & \\
octatriacontane (n-38) & 0.26 & $0.04-0.93$ & IcdP/(IcdP+BghiP) & 0.49 & $0.44-0.54$ \\
nonatriacontane (n-39) & 0.23 & $0.07-0.69$ & & & \\
tetracontane (n-C40) & 0.22 & $0.08-0.42$ & PHE/(PHE+ANT) & 0.76 & $0.69-0.81$ \\
Sum & 32.18 & $6.91-88.79$ & & & \\
CPI & 1.33 & $1.04-1.69$ & & & \\
\hline
\end{tabular}

Table 5. Relationships among carbonaceous species in $\mathrm{PM}_{2.5}$ and TSP.

\begin{tabular}{lllll}
\hline & \multicolumn{2}{c}{$\mathrm{PM}_{2.5}(n=40)$} & \multicolumn{2}{c}{$\mathrm{TSP}(n=40)$} \\
\hline & $R^{2}$ & $p$ & $R^{2}$ & $p$ \\
OC vs EC & 0.34 & $<0.0001$ & 0.46 & $<0.0001$ \\
OC vs char & 0.38 & $<0.0001$ & 0.33 & $<0.0001$ \\
OC vs soot & 0.0004 & 0.89 & 0.30 & 0.0002 \\
EC vs char & 0.75 & $<0.0001$ & 0.86 & $<0.0001$ \\
EC vs soot & 0.16 & 0.01 & 0.39 & $<0.0001$ \\
char vs soot & 0.01 & 0.49 & 0.09 & 0.0580 \\
\hline
\end{tabular}

Xiamen (Zhao et al., 2010), but they were higher than those in other cities including Hong Kong, Valencia, Spain and Los Angeles, USA (Zheng et al., 2000; Guo et al., 2003, 2009; Fraser et al., 1998; Borras and Tortajada-Genaro, 2007). The high PAH concentrations found in our study attest to the seriousness of organic pollution in Shanghai.

BeP and PHE were the most abundant of the PAHs in all samples, followed by BbF and BkF (Fig. 4b). BeP was found to be the most abundant PAH in 15 samples with an average concentration of $1.3 \mathrm{ng} \mathrm{m}^{-3}$ (range: 0.2 to $4.3 \mathrm{ng} \mathrm{m}^{-3}$ ), and it accounted for up to $17 \%$ of the total PAHs determined. PHE exhibited the highest concentration in the other four samples, with a concentration range of 0.2 to $3.4 \mathrm{ng} \mathrm{m}^{-3}\left(1.1 \mathrm{ng} \mathrm{m}^{-3}\right.$ on average); PHE accounted for $\sim 15 \%$ of the PAHs. The average concentration of $\mathrm{B}[\mathrm{b}+\mathrm{k}] \mathrm{F}$ was $1.4 \mathrm{ng} \mathrm{m}^{-3}$, with $\mathrm{B}[\mathrm{b}] \mathrm{F}$ $\left(0.9 \mathrm{ng} \mathrm{m}^{-3}\right)$ slightly higher in concentration than $\mathrm{B}[\mathrm{k}] \mathrm{F}$ $\left(0.5 \mathrm{ng} \mathrm{m}^{-3}\right)$.

The average concentration of $\mathrm{BaP}$ found in the present study $\left(0.5 \mathrm{ng} \mathrm{m}^{-3}\right)$ was lower than some might expect, and there are at least two plausible explanations for this: (1) the sampling site (Pudong) was close to a park and far away from major roadways; therefore, the impacts of fossil-fuel emissions from motor vehicles were likely not very significant; and (2) the average wind speed in Pudong was $\sim 1 \mathrm{~m} \mathrm{~s}^{-1}$ during the sampling period, and those conditions were not favourable for the dispersion of air pollutants. This presumably led to the decomposition of $\mathrm{BaP}$ because this compound readily decomposes through reactions with light and oxidants (Greenberg, 1989; Lee et al., 2001; Chen et al., 2011).

Furthermore, comparisons with other studies show that the $\mathrm{BaP}$ concentrations and $\mathrm{BeP} /(\mathrm{BaP}+\mathrm{BeP})$ ratios we measured at Pudong are in line with those from other cities in Asia. For instance, in a study conducted at Hong Kong, Zheng and Fang (2000) reported an average concentration of $\mathrm{BaP}$ at six sampling sites of $0.5 \mathrm{ng} \mathrm{m}^{-3}$, and this is the same as the $\mathrm{BaP}$ concentration determined in our study. In addition, Feng et al. (2006) found that the ratios of $\mathrm{BeP} /(\mathrm{BaP}+\mathrm{BeP})$ in 
Shanghai were 0.73 in summer and 0.75 in winter, and these ratios also are consistent with results of our study (0.76).

Daily variations in the loadings of the organic aerosols evidently were affected by meteorological conditions, and selected relationships are illustrated in Fig. 3. The highest measured sum of $n$-alkanes and PAHs ( $n$-alk + PAHs, $114.4 \mathrm{ng} \mathrm{m}^{-3}$ ) occurred on 12 September, when the average wind direction was $151^{\circ}$; the lowest loading $\left(8.4 \mathrm{ng} \mathrm{m}^{-3}\right)$ was on 17 September, when the wind direction was $82^{\circ}$. The average $n$-alk + PAHs concentration was $73.5 \mathrm{ng} \mathrm{m}^{-3}$ when the wind directions were greater than $90^{\circ}$, but this dropped to $30.3 \mathrm{ng} \mathrm{m}^{-3}$ when the wind directions were less than $90^{\circ}$. Further analyses showed that high wind speeds most often occurred when the winds came from the east. A negative correlation between the $n$-alk + PAHs concentrations and wind speed was observed ( $r=-0.46$ and -0.37 for $n$-alkanes and PAHs, respectively), and this stands to reason because strong winds can disperse the pollutants. In addition, winds blowing from the East China Sea bring maritime air to Shanghai and this presumably dilutes and disperses the local air pollutants; one would expect that this type of airflow would lead to low concentrations of $n$-alk + PAHs.

\subsection{Stable carbon isotope composition of $\mathrm{OC}$ and $\mathrm{EC}$}

Stable carbon isotope analyses of atmospheric particles have been used for source identification purposes (Gleason et al., 1984; Cachier et al., 1986; Ho et al., 2006; Cao et al., 2008, 2011). For instance, Widory et al. (2004) used a combination of carbon and lead isotopes to distinguish between aerosol sources, such as road traffic versus industrial emissions, in Paris. Agnihotri et al. (2011) used data for carbon and nitrogen isotopes in aerosols to characterize potential aerosol sources for India and the northern Indian Ocean. Stable carbon isotope ratios have been determined for the OC and EC fractions of $\mathrm{PM}_{2.5}$, collected from Hong Kong and 14 Chinese cities, and those studies have shown that stable carbon isotopes are potentially useful for identifying the sources for carbonaceous pollutants (Ho et al., 2006; Cao et al., 2011).

Plots of $\delta^{13} \mathrm{C}_{\mathrm{OC}}$ and $\delta^{13} \mathrm{C}_{\mathrm{EC}}$ show that the average $\delta^{13} \mathrm{C}_{\mathrm{OC}}$ abundance was $-24.5 \pm 0.8 \%$ o (range $-25.6 \%$ o to $-22.6 \%$ ) while the average $\delta^{13} \mathrm{C}_{\mathrm{EC}}$ abundance was $-25.1 \pm 0.6 \%$ o (range $-25.8 \%$ o to $-23.7 \%$, Fig. 5). Variability in the $\delta^{13} \mathrm{C}$ values demonstrate carbon isotope variability in both $\mathrm{EC}$ and OC (Fig. 5), and for purposes of discussion, we separated the samples in into three groups based on wind direction (Groups I, II and III). The dominant wind direction for Groups I and III was ENE-E while for Group II it was SSE-SW. The $\delta^{13} \mathrm{C}_{\mathrm{OC}}$ values for Groups I, II, and III were $-24.7 \%$ o, $-25.0 \%$ and $-23.9 \%$, respectively, while the corresponding values for $\delta^{13} \mathrm{C}_{\mathrm{EC}}$ were $-25.1 \%$, $-24.6 \%$ and $-25.4 \%$. The $\delta^{13} \mathrm{C}_{\mathrm{OC}}$ values of Groups I and III were thus isotopically heavier than those for Group II, while the $\delta^{13} \mathrm{C}_{\mathrm{EC}}$ values of Groups I and III were slightly lighter than Group II.

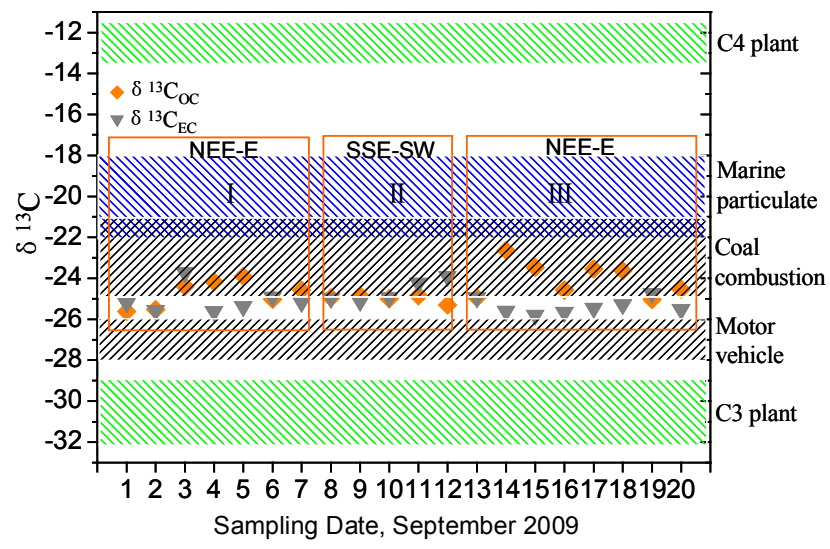

Fig. 5. The variations of stable carbon isotope for $\mathrm{OC}$ and EC at Pudong $\left(\delta^{13} \mathrm{C}\right.$ of major emission sources including coalcombustion (Gleason and Kyser, 1984; Widory, 2006), biomass burning from C3 and C4 plants (Martinelli et al., 2002; Moura et al., 2008), and motor vehicle exhaust (Widory, 2006)).

Previous studies have shown that there is only little fractionation of ${ }^{13} \mathrm{C}$ between a fuel and the aerosols produced by the burning of that fuel (Turekian et al., 1998; Currie et al., 1999), and there is no apparent isotopic fractionation during particle production and transport, at least in the tropics (Cachier et al., 1985). Similarities in the OC and EC isotopic composition for Groups I and III suggest contributions from the same or functionally comparable sources. Cachier et al. (1986) reported that the $\delta^{13} \mathrm{C}$ associated with sea salt droplets is $-21 \pm 2 \%$. The less negative $\delta^{13} \mathrm{C}_{\mathrm{OC}}$ values for Groups I and III compared with Group II (Fig. 5) could thus be explained by the sampling of isotopically heavy marine aerosols transported from the East China Sea under maritime flow.

The isotopic composition for Group II indicates that the $\mathrm{PM}_{2.5}$ was affected by fossil fuel combustion emissions as well as natural sources, most likely soils and live vegetation. The $\delta^{13} \mathrm{C}_{\mathrm{EC}}$ values for the three groups were similar to those reported previously by Cao et al. (2011), who suggested that the majority of the EC originated from motor vehicle emissions and coal combustion. The results also indicated that $\delta^{13} \mathrm{C}_{\mathrm{OC}}$ was more strongly influenced by mixed sources than $\delta^{13} \mathrm{C}_{\mathrm{EC}}$, and this, too, is consistent with a prior study (Ho et al., 2006).

\subsection{Diagnostic ratios for evaluating carbonaceous aerosol sources}

For several decades, various diagnostic ratios, such as OC/EC, have been used to gain insights into the sources, transport, aging, etc. of carbonaceous aerosols (Gray et al., 1986; Castro et al. 1999; Cao et al., 2003; Chow et al., 1993; Turpin et al., 1995, 2001; Zeng and Wang, 2011). Similar OC/EC values observed for $\mathrm{PM}_{2.5}$ and TSP point to a common source for carbonaceous aerosols in Shanghai, most 
likely coal combustion and motor vehicle emissions. The average OC/EC values for $\mathrm{PM}_{2.5}$ and TSP were 3.8 and 4.3, respectively, and these relatively high values imply the existence of significant quantities of SOA. In this regard, Chow et al. (1996) pointed out that OC/EC ratios $>2.0$ indicate the existence of SOA.

While no single ratio can provide a full picture of the carbonaceous aerosol, several complementary ratios can be used to obtain a more comprehensive understanding of it. Indeed, the char to soot concentration ratio was used by Han et al. (2009) to trace sources for EC in Xi' an, China. The average char/soot ratios in our study were 2.2 and 1.5 for $\mathrm{PM}_{2.5}$ and TSP, respectively, and these values imply stronger contributions from motor vehicle exhaust and coal combustion compared with biomass burning (for source signatures see Fig. 6 of Han et al., 2010). The lack of correlation between OC/EC and char/soot ratios $\left(R^{2}=0.003, p=0.75\right.$, graph not shown) indicates the two ratios were likely affected by different sources and this is consistent with the results of Han et al. (2009).

In addition to the OC/EC and char/soot ratios, several PAHs with diagnostic value and several ratios of PAHs were used to obtain additional information on the sources and aging of organic aerosols. The concentration of BghiP, which has been used as an indicator of emissions from gasoline powered vehicles (Currie et al., 1994; Omar et al., 2002), was determined to be 0.07 to $1.4 \mathrm{ng} \mathrm{m}^{-3}$ (average $0.4 \mathrm{ng} \mathrm{m}^{-3}$ ). These BghiP concentrations are lower than those observed in previous studies in Shanghai and other Chinese cities (Bi et al., 2002; Feng et al., 2006a, b; Okuda et al., 2010; Zhao et al., 2010), suggesting that the automobile emissions in the Pudong area are weaker than in some other cities.

The IcdP/(IcdP + BghiP) ratio has been found to be useful for source assessments: ratios of $0.18,0.37$, and 0.56 were reported for gasoline vehicles, diesel vehicles, and coal burning, respectively (Grimmer et al., 1983). The IcdP/(IcdP + BghiP) ratios, which ranged from 0.44 to 0.54 ( 0.49 on average) in the present study, are similar to or slightly higher than those in the previous investigations in Shanghai (Feng et al., 2006a, b; Gu et al., 2010). These relatively high ratios are consistent with the suggestion that a mixture of motor vehicle exhaust and coal burning emissions are the strongest sources for PAHs in Shanghai.

Khalili et al. (1995) reported that PHE/(PHE+ANT) was 0.5 for gasoline, 0.65 for diesel emissions, and 0.76 for coal combustion, and we used this ratio to further evaluate the contributions of potential PAH sources. The $\mathrm{PHE} /(\mathrm{PHE}+\mathrm{ANT})$ ratios in our study ranged from 0.69 to 0.81 (average $=0.76)$ : this suggests that coal combustion was the dominant source for PAHs and that the incomplete combustion of other fossil fuels, especially diesel oil, also may also contribute to the ambient PAHs. The analyses of other diagnostic ratios \{ANT/(ANT+PHE), FLU/(FLU+PYR), $\mathrm{IcdP} /(\mathrm{IcdP}+\mathrm{BghiP}), \mathrm{BaA} /(\mathrm{BaA}+\mathrm{CHR})$ all point to coal combustion as the dominant contributor to the organic component of $\mathrm{PM}_{2.5}$ (see Figs. 1 to 4 in the Supplement).

Data for PAHs also can be used to assess photochemical degradation. In particular, the $\mathrm{BeP} /(\mathrm{BeP}+\mathrm{BaP})$ ratio has been used as to evaluate the degradation of $\mathrm{BaP}$ and the aging of aerosols (Nielsen, 1988). Most freshly emitted aerosols have a $\mathrm{BeP} /(\mathrm{BeP}+\mathrm{BaP})$ ratio of $\sim 0.5$, but the ratio increases as the particles age (Grimmer et al., 1983). The $\mathrm{BeP} /(\mathrm{BeP}+$ $\mathrm{BaP})$ ratio was 0.76 on average in Shanghai, with a maximum value of 0.85 (Table 4). A time series of $\mathrm{BeP} /(\mathrm{BaP}+\mathrm{BeP})$ was plotted in to show the trends in the ratio over the course of the study, and this is included as Fig. 5 in the Supplement. We hasten to note that the elevated $\mathrm{BeP} /(\mathrm{BeP}+\mathrm{BaP})$ ratios may reflect not only the degradation of $\mathrm{BaP}$, but also potentially the impacts from non-local and/or other aged aerosols. It is also worth noting that the large amounts of SOA that we observed are another indication of aerosol aging.

In summary, the high OC/EC ratios are evidence that SOA is an important component of the carbonaceous aerosol; and the high char/soot ratios indicate that the contributions to EC from motor vehicle exhaust and coal combustion are stronger than those from biomass burning. Our analyses also have shown that the concentrations and ratios of PAHs have diagnostic value for source assessments; more specifically, these results highlight the dominant contribution from coal combustion to the organic aerosol, and they further support our contention regarding the existence of large amounts of SOA.

\subsection{Estimates of the relative source contributions to the carbonaceous aerosols}

The major emission sources for carbonaceous aerosols were evaluated qualitatively above by considering data for chemical indicators and diagnostic ratios. Here, an EC tracer method and isotope mass balance approach was combined to estimate more quantitatively the relative contributions of various sources to carbonaceous $\mathrm{PM}_{2.5}$. The EC tracer method we employed has been used to estimate the quantity of SOC (Castro et al. 1999; Turpin et al., 2001; Cao et al., 2003). For this, primary OC (POC) is first estimated as follows

$\mathrm{POC}=a+b \mathrm{EC}$,

where $a$ and $b$ are the intercept and slope, respectively, of the linear regression of POC on EC. The product $b \mathrm{EC}$ represents the POC associated with combustion sources (e.g., coal combustion and traffic). The intercept $a$, is assumed to be the POC background. SOC is calculated as the difference between the total measured OC and POC (Eq. 1):

$\mathrm{SOC}=\mathrm{OC}-\mathrm{POC}$.

The underlying assumption of this method is that at a given location in a particular season, there is a fixed relationship between POC and EC, that is, the OC/EC ratio (the slope) and the OC background concentration (the intercept) approach constant values. Clearly, the validity of the primary 


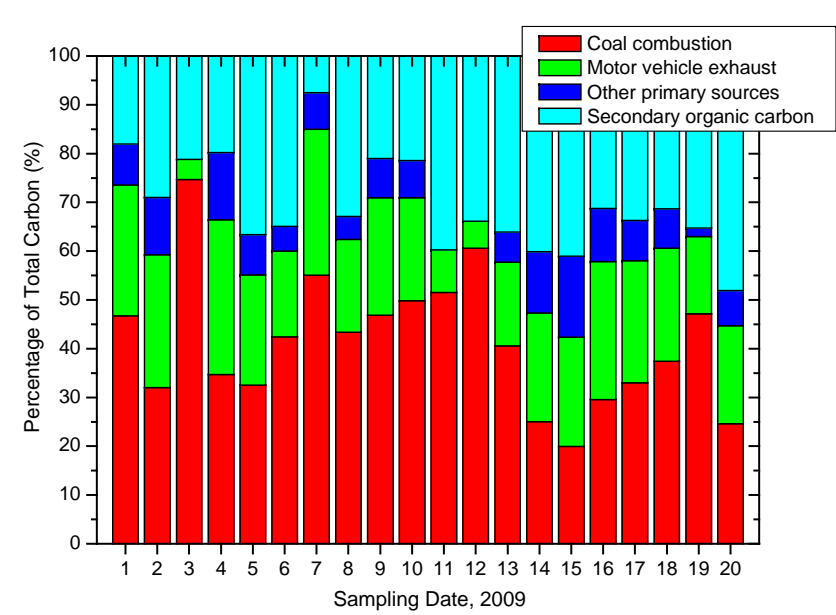

Fig. 6. Relative contributions of different sources to total carbon during 1-20 September 2009.

OC/EC ratio used in the EC tracer model is crucial for the successful application of the technique. Here, the primary OC/EC ratio was approximated from the $10 \%$ of the samples that had the lowest OC/EC ratios (Lim and Turpin, 2002); the details for this calculation have been described in Cao et al. (2007). The SOC fraction of total carbon (TC) was estimated based on the empirically-derived OC/EC ratio of 2.2, and the average percentage of SOC in TC calculated in this way was $30.8 \%$ and ranged widely, from $0.25 \%$ to $61.6 \%$.

As discussed in Sect. 3.3, the major sources for EC in Shanghai are thought to be coal combustion and motor vehicle exhaust, with only a minor contribution from biomass burning. Indeed, five diagnostic ratios of PAHs: (1) BghiP/BeP, (2) PHE/(PHE+ANT), (3) FLU/(FLU+PYR), (4) $\mathrm{BbF} / \mathrm{BkF}$, and (5) BghiP/IP, all indicate that the organic aerosol was strongly influenced by biomass burning on only two days, 7 and 8 September. The concentrations of OC were 3.4 and $6.8 \mu \mathrm{g} \mathrm{m}^{-3}$ in the day and at night on 7 September and 4.9 and $6 \mu \mathrm{g} \mathrm{m}^{-3}$ during the day and night on 8 September (Fig. 1). EC concentrations were $1.3 \mu \mathrm{g} \mathrm{m}^{-3}$ (day) and 2.9 (night) $\mu \mathrm{g} \mathrm{m}^{-3}$ on 7 September and $1.6 \mu \mathrm{g} \mathrm{m}^{-3}$ (day) and $1.3 \mu \mathrm{g} \mathrm{m}^{-3}$ (night) on 8 September. Indeed, the concentrations of both OC and EC during this period were less than average, and this is further evidence that biomass burning was not an important source for carbonaceous aerosols during most of our observation period.

If one assumes that the influence of biomass burning on EC is negligible, the relative contributions of coal combustion and motor vehicle exhaust can be estimated using the isotope mass balance approach for $\delta^{13} \mathrm{C}_{\mathrm{EC}}$. The focus here is on $\mathrm{EC}$ because this is the fraction of the carbonaceous aerosol that retains the original signature of the primary emissions. The mass balance model for $\delta^{13} \mathrm{C}_{\mathrm{EC}}$ is as follows

$\delta^{13} \mathrm{C}_{\mathrm{ECAM}}=\mathrm{X}_{\mathrm{CC}} \delta^{13} \mathrm{C}_{\mathrm{EC} \mathrm{CC}}+\mathrm{X}_{\mathrm{MV}} \delta^{13} \mathrm{C}_{\mathrm{EC} \mathrm{MV}}$, where $\delta^{13} \mathrm{C}_{\mathrm{EC}}$ AM denotes the $\delta^{13} \mathrm{C}_{\mathrm{EC}}$ of ambient samples, $\delta^{13} \mathrm{C}_{E C} C C$ denotes the $\delta^{13} \mathrm{C}_{\mathrm{EC}}$ of the coal combustion (CC) source, $\delta{ }^{13} \mathrm{C}_{E C} M V$ denotes the $\delta^{13} \mathrm{C}_{\mathrm{EC}}$ of motor vehicle (MV) exhaust, and $\mathrm{X}_{\mathrm{CC}}$ and $\mathrm{X}_{\mathrm{MV}}$ denote the percent contributions from CC and MV exhaust, respectively.

Mori et al. (1999) reported that $\delta^{13} \mathrm{C}$ of Chinese coal was $-23.4 \pm 1.2 \%$, and Widory et al. (2006) reported that $\delta^{13} \mathrm{C}$ of motor vehicle exhaust ranged from $-26 \%$ to $-28 \%$. We adopted these values $(-23.4 \%$ and $-27 \%$ ) as the isotopic source signatures for coal combustion products and motor vehicle exhaust to calculate their relative contributions from Eq. (3). The average percent contributions to EC calculated in this way were $53 \%$ (ranged from $52 \%$ to $57 \%$ ) for CC and $47 \%$ (ranged from $42 \%$ to $48 \%$ ) for MV when considering the uncertainties of isotopic values from the literature. Although this simple model has only two components, the stable carbon isotope data show roughly comparable contributions from these two sources.

Watson et al. (2001) reported OC/EC ratios of 2.7 for CC and 1.1 for MV, and we can use this information to calculate the amount of primary $\mathrm{OC}$ from $\mathrm{CC}$ and $\mathrm{MV}\left(\mathrm{POC}_{\mathrm{CC}+\mathrm{MV}}\right)$ by using Eq. (4).

$$
\mathrm{POC}_{\mathrm{CC}+\mathrm{MV}}=\mathrm{POC}_{\mathrm{CC}}+\mathrm{POC}_{\mathrm{MV}}=2.7 \times \operatorname{coal}(\%)
$$

$+1.1 \times$ motor vehicle $(\%)$

The fraction of primary $\mathrm{OC}$ from other sources ( $\left.\mathrm{POC}_{\text {others }}\right)$, such as marine, soil and biogenic emissions, can be estimated from Eq. (5).

$\mathrm{POC}_{\text {others }}=\mathrm{POC}-\mathrm{POC}_{\mathrm{CC}+\mathrm{MV}}$.

The percent contributions to total carbon from $\mathrm{CC}, \mathrm{MV}$, other primary sources and SOC can be calculated from the equation 6 , and the results of these calculations are plotted in Fig. 6.

$$
\begin{aligned}
& \mathrm{TC}=\mathrm{OC}+\mathrm{EC}=\mathrm{POC}+\mathrm{SOC}+\mathrm{EC}=\mathrm{POC}_{\mathrm{CC}+\mathrm{MV}} \\
& +\mathrm{POC}_{\mathrm{others}}+\mathrm{SOC}+\mathrm{EC}_{\mathrm{CC}+\mathrm{MV}}=\mathrm{POC}_{\mathrm{CC}}+\mathrm{POC}_{\mathrm{MV}} \\
& +\mathrm{POC}_{\mathrm{others}}+\mathrm{SOC}+\mathrm{EC}_{\mathrm{CC}}+\mathrm{EC}_{\mathrm{MV}}=(\mathrm{POC}+\mathrm{EC})_{\mathrm{CC}} \\
& +(\mathrm{POC}+\mathrm{EC})_{\mathrm{MV}}+\mathrm{POC}_{\text {others }}+\mathrm{SOC}
\end{aligned}
$$

The average percent contributions to $\mathrm{TC}$ attributable to $\mathrm{CC}$, $\mathrm{MV}$, other primary sources (marine, soil, biogenic emissions, etc.), and SOC calculated from equation 6 were $41 \%, 21 \%$, $7 \%$, and $31 \%$, respectively. For the organic pollution event on 12 September, the contribution from coal combustion was estimated to be $9.6 \mu \mathrm{g} \mathrm{m}^{-3}$; this amounts to $61 \%$ of the TC and implies that the coal combustion is a dominant source for carbonaceous particles during heavy air pollution episodes (Wang et al., 2006; Yao et al., 2002). The PM concentrations emitted from motor vehicles amounted to $\sim 2 \mu \mathrm{g} \mathrm{m}^{-3}$ on most of days, implying relatively constant inputs from this source.

We calculated the amounts of secondary organic matter (SOM) and primary organic matter (POM) from mass conversion factors following the approach of Turpin and Lim 
(2001). It is worth pointing out that POM is mostly composed of insoluble compounds, while, in contrast, the oxidation products of photochemical reactions that compose SOM are usually soluble in water. The mass of POM was assumed to be 1.3 times POC, and SOM mass was estimated as 3.2 times the SOC concentration. Hence, the average percentages of $\mathrm{CC}, \mathrm{MV}$, other primary sources and SOA in $\mathrm{PM}_{2.5}$ by mass were $11 \%, 6 \%, 26 \%$, and $22 \%$, respectively. The sum of the carbonaceous pollutants thus accounted for $42 \%$ of the $\mathrm{PM}_{2.5}$ mass. These results highlight the importance of controlling the sources for carbonaceous particulates when measures are taken to reduce fine particle pollution in Shanghai. Finally, we note that the OC/EC ratios for the major sources considered here were taken from literature (Watson et al., 2001) because there are no data for the local Shanghai sources. More accurate representations of the sources in Shanghai will lead to more robust source apportionments in the future.

\section{Implications}

Our study shows that data for OC/EC, PAHs, $n$-alkanes, and stable carbon isotopes in $\mathrm{OC}$ and $\mathrm{EC}$ obtained from single quartz-fiber filters provide insights into the sources, formation, and degradation of carbonaceous particles. The three types of analyses used in the study are suitable for routine monitoring. Unlike more complex analytical systems, the three types of analyses performed here could be implemented by local environmental protection agencies in China or elsewhere with relative ease. $\mathrm{PM}_{2.5}$ pollution has become a hot topic in China, and the Chinese government issued a national $\mathrm{PM}_{2.5}$ standard on February 29, 2012, that requires cities to have concentrations below $35 \mu \mathrm{g} \mathrm{m}^{-3}$ as annual average and $<75 \mu \mathrm{g} \mathrm{m}^{-3}$ for 24-hr, beginning in 2016 (http://cleanairinitiative.org/portal/node/8163). From a survey of the literature, we found that current levels of $\mathrm{PM}_{2.5}$ in many if not most Chinese cities will exceed the new daily $\left(75 \mu \mathrm{g} \mathrm{m}^{-3}\right)$ and yearly $\left(35 \mu \mathrm{g} \mathrm{m}^{-3}\right) \mathrm{PM}_{2.5}$ standards.

Knowledge of the source contributions of $\mathrm{PM}_{2.5}$ is needed to effectively control $\mathrm{PM}_{2.5}$ pollution, and obtaining this information should be a top priority for the cities and provinces in China. The approach we advocate, that is, the analyses and interpretation of data for OC, EC, PAHs, $n$-alkanes, and isotopes, will provide a powerful tool for source apportionment studies of the carbonaceous aerosol, not only for Chinese cities but also throughout the world.

\section{Conclusions}

Combined analyses of OC and EC, $n$-alkanes and PAHs, and stable carbon isotopes undertaken for the MIRAGEShanghai 2009 Experiment were used to investigate the sources of particulate carbonaceous pollutants. Concentrations and temporal variations of OC, EC, char, soot, C17-40 $n$-alkanes, and 17 PAHs showed that carbonaceous aerosols are a major component of the fine particle population, accounting for $42 \%$ of the $\mathrm{PM}_{2.5}$ mass. High OC/EC ratios indicated the existence of significant but rather variable amounts of secondary organic aerosol (SOA), and while studies are needed to determine the particle-size distribution of this material, it is likely that much of the SOA is associated with ultrafine particles and thus a serious concern for human health.

High char/soot ratios indicated that the contributions from motor vehicle exhaust and coal combustion to primary EC were larger than that from biomass burning. Diagnostic ratios of selected PAHs indicated a prevailing impact from coal combustion on the organic species as well as the existence of large amounts of SOA. The relative abundances of stable carbon isotopes, measured as $\delta^{13} \mathrm{C}_{\mathrm{OC}}$ and $\delta^{13} \mathrm{C}_{E C}$, suggested that the burning of fossil fuels was the most important source for carbonaceous $\mathrm{PM}_{2.5}$, but lesser impacts from natural sources, such as sea salt, soils and live vegetation also were evident.

A combined EC tracer and isotope mass-balance approach indicated that the average relative contributions of coal combustion, motor vehicle exhaust, and other primary sources such as sea salt, soil and biogenic emissions in total carbon were $41 \%, 21 \%$, and $7 \%$, respectively, while SOA accounted for $31 \%$ of the total carbon. Variations in the source contributions to the carbonaceous aerosol are driven by emissions and removal, and these processes are influenced meteorological factors, most notably wind speed, wind direction, mixing-layer depth, precipitation, and solar radiation flux. Carbonaceous particles are a major cause of high $\mathrm{PM}_{2.5}$ loadings, and the findings presented here concerning the sources for these particles provide a starting point for developing effective strategies for pollution control.

\section{Supplementary material related to this article is available online at: http://www.atmos-chem-phys.net/13/ 803/2013/acp-13-803-2013-supplement.pdf.}

Acknowledgements. This study was supported by the National Natural Science Foundation of China (40925009, 41230641), the "Strategic Priority Research Program" of the Chinese Academy of Sciences (XDA05100401), and National Gongyi Project (201209007). The authors are grateful to Yingying Li and Haiyan $\mathrm{Lu}$ for their assistance in the aerosol sampling and analyses.

Edited by: C. H. Song 


\section{References}

Agnihotri, R. Mandal, T. K., Karapurkar, S., Naja, M., Gadi, R., Ahammed, Y. N., Kumar, A., Saud, T., and Saxena, M.: Stable carbon and nitrogen isotopic composition of bulk aerosols over India and northern Indian Ocean, Atmos. Environ., 45, 28282835, 2011.

Arimoto, R., Duce, R. A., Savoie, D. L., Prospero, J. M., Talbot, R., Cullen, J. D., Tomza, U., Lewis, N. F., and Ray, B. J.: Relationships among aerosol constituents from Asia and the North Pacific during PEM-West A, J. Geophys. Res., 101, 2011-2023, 1996.

Bi, X. H., Sheng, G. Y., Peng, P. A., Zhang Z. Q., and Fu, J. M.: Extractable organic matter in PM from LiWan district of Guangzhou City, PR China, Sci. Total Environ., 300, 213-228, 2002.

Bi, X. H., Simoneit, R. T. B., Sheng, G. Y., Ma, S. X., and Fu, J. M.: Composition and major sources of organic compounds in urban aerosols, Atmos. Res., 88, 256-265, 2008.

Borras, E. and Tortajada-Genaro, L. A.: Characterisation of polycyclic aromatic hydrocarbons in atmospheric aerosols by gas chromatography-mass spectrometry, Anal. Chim. Acta, 583, 266-276, 2007.

Cachier, H., Buat-Menard, P., and Fontugne, M.: Source terms and source strengths of the carbonaceous aerosol in the tropics, J. Atmos. Chem. 3, 469-489, 1985.

Cachier, H., Buat-Menard, P., Fontugne, M., and Chesselet, R.: Long-range transport of continentally-derived particulate carbon in the marine atmosphere: evidence from stable carbon isotopes studies, Tellus 38B, 161-177, 1986.

Cao, J. J., Lee, S. C., Ho, K. F., Zhang, X. Y., Zou, S. C., Fung, K. K., Chow, J. C., and Watson, J. G.: Characteristics of carbonaceous aerosol in Pearl River Delta Region, China during 2001 winter period, Atmos. Environ., 37, 1451-1460, 2003.

Cao, J. J., Lee, S. C., Ho, K. F., Zou, S. C., Fung, K., Li, Y., Watson, J. G., and Chow, J. C.: Spatial and seasonal variations of atmospheric organic carbon and elemental carbon in Pearl River Delta Region, China, Atmos. Environ., 38, 4447-4456, 2004.

Cao, J. J., Wu, F., Chow, J. C., Lee, S. C., Li, Y., Chen, S. W., An, Z. S., Fung, K. K., Watson, J. G., Zhu, C. S., and Liu, S. X.: Characterization and source apportionment of atmospheric organic and elemental carbon during fall and winter of 2003 in Xi' an, China, Atmos. Chem. Phys., 5, 3127-3137, doi:10.5194/acp-53127-2005, 2005.

Cao, J. J., Lee, S. C., Chow, J. C., Watson, J. G., Ho, K. F., Zhang, R. J., Jin, Z. D., Shen, Z. X., Chen, G. C., Kang, Y. M., Zou, S. C., Zhang, L. Z., Qi, S. H., Dai, M. H., Cheng, Y., and Hu, K.: Spatial and seasonal distributions of carbonaceous aerosols over China, J. Geophys. Res., 112, D22S11, doi:10.1029/2006JD008205, 2007.

Cao, J. J., Zhu, C. S., Chow, J. C., Liu, W. G., Han, Y. M., and Watson, J. G.: Stable carbon and oxygen isotopic composition of carbonate in fugitive dust in the Chinese Loess Plateau, Atmos. Environ., 42, 9118-9122, 2008.

Cao, J. J., Chow, J. C., Tao, J., Lee, S. C., Watson, J. G., Ho, K. F., Wang, G. H., Zhu, C. S., and Han, Y. M.: Stable carbon isotopes in aerosols from Chinese cities: Influence of fossil fuels, Atmos. Environ., 45, 1359-1363, 2011.

Cass, G. R.: Organic molecular tracers for particulate air pollution sources, Trends Anal. Chem., 17, 356-366, 1998.
Castro, L. M., Pio, C. A., Harrison, R. M., and Smith, D. J. T.: Carbonaceous aerosol in urban and rural European atmospheres: estimation of secondary organic carbon concentrations, Atmos. Environ., 33, 2771-2781, 1999.

Charlson, R. J., Scharwtz, S. E., Hales, J. M., Cess, R. D., Coakley Jr., J. A., Hansen, J. E., and Hofman, D. J.: Climate forcing by anthropogenic aerosols, Science, 255, 423-430, 1992.

Chen, Y. J., Feng, Y. L., Xiong, S. C., Liu, D. Y., Wang, G., Sheng, G. Y., and Fu, J. M.: Polycyclic aromatic hydrocarbons in the atmosphere of Shanghai, China, Environ. Monit. Assess., 172, 235-247, 2011.

Chow, J. C., Watson, J. G., Lu, Z., Lowenthal, D. H., Frazier, C. A.,Solomon, P. A., Thuillier, R. H., and Magliano, K. L.: Descriptiveanalysis of PM2.5 and PM10 at regionally representativelocations during SJVAQS/AUSPEX, Atmos. Environ., 30, 2079-2112, 1996.

Chow, J. C., Watson, J. G., Kuhns, H. D., Etyemezian, V., Lowenthal, D. H., Crow, D. J., Kohl, S. D., Engelbrecht, J. P., and Green, M. C.: Source profiles for industrial, mobile, and area sources in the Big Bend Regional Aerosol Visibility and Observational (BRAVO) Study, Chemosphere, 54, 185-208, 2003.

Chow, J. C., Watson, J. G., Pritchett, L. C., Pierson, W. R., Frazier, C. A., and Purcell, R. G.: The DRI thermal/optical reflectance carbon analysis system: Description, evaluation and applications in U.S. air quality studies, Atmos. Environ., 27, 1185-1201, 1993.

Chow, J. C., Watson, J. G., Chen, L. W. A., Arnott, W. P., Moosmuller, H., and Fung, K. K.: Equivalence of elemental carbon by thermal/optical reflectance and transmittance with different temperature protocols, Environ. Sci. Technol., 38, 4414-4422, 2004

Chow, J. C., Yu, J. Z., Watson, J. G., Ho, S. S. H., Bohannan, T. L., Hays, M. D., and Fung, K. K.: The application of thermal methods for determining chemical composition of carbonaceous aerosols: a review, J. Environ. Sci. Health, Part A, 42, 15211541, 2007.

Currie, L. A., Klouda, G. A., Benner, B. A., Garrity, K., and Eglinton, T. I.: Isotopic and molecular fractionation in combustion; three routes to molecular marker validation, including direct molecular dating (GC/AMS), Atmos. Environ., 33, 2789-2806, 1999.

Currie, L. A., Klouda, G. A., Klinedinst, D. B., Sheffield, A. E., Jull, A. J. T., Donahue, D. J., and Connolly, M. V.: Fossil- and bio-mass combustion: C-14 for source identification, chemical tracer development, and model validation, Nucl. Instrum. Methods., B92, 404-409, 1994.

Dockery, D. W., Pope, C. A., Xu, X., Spengler, J. D., Ware, J. H., Fay, M. E., Ferris, B. G., and Speizer, F. E.: An association between air pollution and mortality in six U.S. cities, New Engl. J. Med., 329, 1753-1759, 1993.

Duan, F. K., He, K. B., Ma, Y. L., Yang, F. M., Yu, X. C., Cadle, S. H., Chan, T., and Mulawa, P. A.: Concentration and chemical characteristics of $\mathrm{PM}_{2.5}$ in Beijing, China: 2001-2002, Sci. Total Environ., 355, 264-275, 2006.

Feng, J. L., Chan, C. K., Fang, M., Hu, M., He, L. Y., and Tang. X. Y.: Characteristics of organic matter in $\mathrm{PM}_{2.5}$ in Shanghai, Chemosphere, 64, 1393-1400, 2006a.

Feng, J. L., Hu, M., Chan, C. K., Lau, P. S., Fang, M., He, L. Y., and Tang, X. Y.: A comparative study of the organic matter in $\mathrm{PM}_{2.5}$ from three Chinese megacities in three different climatic zones, 
Atmos. Environ., 40, 3983-3994, $2006 \mathrm{~b}$.

Feng, Y. L., Chen, Y. J., Guo, H., Zhi G. R., Xiong, S. C., Li, J., Sheng, G. Y., and Fu, J. M.: Characteristics of organic and elemental carbon in $\mathrm{PM}_{2.5}$ samples in Shanghai, China, Atmos. Res., 92, 434-442, 2009.

Fraser, M. P., Cass, G. R., and Simoneit, B. R. T.: Gas-phase and particle-phase organic compounds emitted from motor vehicle traffic in a Los Angeles roadway tunnel, Environ. Sci. Technol., 32, 2051-2060, 1998

Friedli, H. R., Arellano Jr., A. F., Geng, F., Cai, C., and Pan, L.: Measurements of atmospheric mercury in Shanghai during September 2009, Atmos. Chem. Phys., 11, 3781-3788, doi:10.5194/acp-11-3781-2011, 2011

Gleason, J. D. and Kyser, T. K.: Stable isotope compositions of gases and vegetation near naturally burning coal, Nature, 307, 254-257, 1984.

Gray, H. A., Cass, G. R., Huntzicker, J. J., Heyerdahl, E. K., and Rau, J. A.: Characterization of atmospheric organic and elemental carbon particle concentrations in Los Angeles, Sci. Total Environ., 20, 580-589, 1986.

Greenberg, A.: Phenomenological study of benzo[a]pyrene and cyclopenteno[cd]pyrene decay in ambient air using winter/summer comparisons, Atmos. Environ., 23, 2797-2799, 1989.

Grimmer, G., Jacob, J., and Naujack, K. W.: Profile of the polycyclic aromatic compounds from crude oils. 3. Inventory by GC, GC/MSPAH in environmental materials, Fresen. Z. Anal. Chem. 316, 29-36, 1983.

Gu, Z. P., Feng, J. L., Han, W. L., Li, L., Wu, M. H., Fu, J. M., and Sheng, G. Y.: Diurnal variations of polycyclic aromatic hydrocarbons associated with PM2.5 in Shanghai, China, J. Environ. Sci., 22, 389-396, 2010.

Guo, Z. G., Lin, T., Zhang, G., Hu, L. M., and Zheng, M.: Occurrence and sources of polycyclic aromatic hydrocarbons and $n$ alkanes in $\mathrm{PM}_{2.5}$ in the roadside environment of a major city in China, J. Hazard. Mater., 170, 888-894, 2009.

Guo, Z. G., Sheng, L. F., Feng, J. L., and Fang, M.: Seasonal variation of solvent extractable organic compounds in the aerosols in Qingdao, China, Atmos. Environ., 37, 1825-1834, 2003.

Han, Y. M., Cao, J. J., Chow, J. C., Watson, J. G., Fung, K. K., Jin, Z. D., Liu, S. X., and An, Z. S.: Evaluation of the thermal/optical reflectance method for discrimination between soot- and charEC, Chemosphere 69, 569-574, 2007.

Han, Y. M., Lee, S. C., Cao, J. J., Ho, K. F., and An, Z. S.: Spatial distribution and seasonal variation of char-EC and soot-EC in the atmosphere over China, Atmos. Environ., 43, 6066-6073, 2009.

Han, Y. M., Cao, J. J., Lee, S. C., Ho, K. F., and An, Z. S.: Different characteristics of char and soot in the atmosphere and their ratio as an indicator for source identification in Xi' an, China, Atmos. Chem. Phys., 10, 595-607, doi:10.5194/acp-10-595-2010, 2010.

He, L. Y., Hu, M., Huang, X. F., Zhang, Y. H., and Tang, X. Y.: Seasonal pollution characteristics of organic compounds in atmospheric fine particles in Beijing, Sci. Total Environ., 359, 167176, 2006.

He, K., Yang, F., Ma, Y., Zhang, Q., Yao, X., Chan, C. K., Cadle, S., Chan, T., and Mulawa, P.: The characteristics of $\mathrm{PM}_{2.5}$ in Beijing, China, Atmos. Environ., 35, 4959-4970, 2001.

Ho, K. F., Lee, S. C., Cao, J. J., Li, Y. S., Chow, J. C., Watson, J. G., and Fung, K.: Variability of organic and elemental carbon, water soluble organic carbon, and isotopes in Hong Kong, At- mos. Chem. Phys., 6, 4569-4576, doi:10.5194/acp-6-4569-2006, 2006.

Ho, S. S. H. and Yu, J. Z.: In-injection port thermal desorption and subsequent gas chromatography-mass spectrometric analysis of polycyclic aromatic hydrocarbons and $n$-alkanes in atmospheric aerosol samples, J. Chromatogr. A., 1059, 121-129, 2004.

Ho, S. S. H, Yu, J. Z., Chow, J. C., Zielinska, B., Watson, J. G., Sit, E. H. L., and Schauer, J. J.: Evaluation of an in-injection port thermal desorption-gas chromatography/mass spectrometry method for analysis of non-polar organic compounds in ambient aerosol samples, J. Chromatogr. A., 1200, 217-227, 2008.

Ho, S. S. H, Chow, J. C., Watson, J. G., Ng, L. P. T., Kwok, Y., Ho, K. F., and Cao, J. J.: Precautions for in-injection port thermal desorption-gas chromatography/mass spectrometry (TDGC/MS) as applied to aerosol filter samples, Atmos. Environ., 45, 1491-1496, 2011.

Hou, X. M., Zhuang, G. S., Sun, Y. L., and An, Z. S.: Characteristics and sources of polycyclic aromatic hydrocarbons and fatty acids in $\mathrm{PM}_{2.5}$ aerosols in dust season in China, Atmos. Environ., 40, 3251-3262, 2006.

Huang, H., Zou, C. W., Cao, J. J., and Tsang, P. K.: Carbonaceous Aerosol Characteristics in Outdoor and Indoor Environments of Nanchang, China, during Summer 2009,J. Air Waste Manage. Assoc., 61, 1262-1272, 2011.

Intergovernmental Panel on Climate Change (IPCC) Climate Change 2007: The Physical Science Basic, in: Changes in atmospheric constituents and in radiative forcing, edited by: Forster, P., Ramaswamy, V., Artaxo, P., Berntsen, T., Betts, R., Fahey, D. W., Haywood, J., Lean, J., Lowe, D. C., Myhre, G., Nganga, J., Prinn, R., Raga, G., Schulz, M., and Dorland, R. V., Cambridge University Press, UK, 129-234, 2007.

Jacobson, M. C., Hansson, H. C., Noone, K. J., and Charlson, R. J.: Organic atmospheric aerosols: review and state of the science, Rev. Geophys., 38, 267-294, 2000.

Khalili, N. R., Scheff, P. A., and Holsen, T. M.: PAH source fingerprints for coke ovens, diesel and gasoline engines, highway tunnels, and wood combustion emissions, Atmos. Environ., 29, 533-542, 1995.

Kim, K. H., Sekiguchi, K., Furuuchi, M., and Sakamoto, K.: Seasonal variation of carbonaceous and ionic components in ultrafine and fine particles in an urban area of Japan. Atmos. Environ., 45, 1581-1590, 2011a.

Kim, K. H., Sekiguchi, K., Kudo, S., and Sakamoto, K.: Characteristics of Atmospheric Elemental Carbon (Char and Soot) in Ultrafine and Fine Particles in a Roadside Environment, Japan. Aerosol Air Qual. Res., 11, 1-12, 2011 b.

Kuhlbusch, T. A. J.: Black carbon in soils, sediments, and ice cores, in: Environmental analysis and remediation, edited by: Meyers, R. A., John Wiley \& Sons, Toronto, Canada, 813-823, 1997.

Lee, S. C., Ho, K. F., Chan, L. Y., Zielinska, B., and Chow, J. C.: Polycyclic aromatic hydrocarbons (PAHs) and carbonyl compounds in urban atmosphere of Hong Kong, Atmos. Environ., 35, 5949-5960, 2001.

Li, W. F., Peng, Y., and Bai, Z. P.: Distributions and sources of $n$ alkanes in $\mathrm{PM}_{2.5}$ at urban, industrial and coastal sites in Tianjin, China, J. Environ. Sci., 22, 1551-1557, 2010.

Lim, H. J. and B. J. Turpin, Origins of primary and secondary organic aerosol in Atlanta: Results of time-resolved measurements during the Atlanta supersite experiment, Environ. Sci. Technol., 
36, 4489-4496, 2002.

Masiello, C. A.: New directions in black carbon organic geochemistry, Mar. Chem., 92, 201-213, 2004.

Mauderly, J. L. and Chow, J. C.: Health effects of organic aerosols, Inhal. Toxicol., 20, 257-288, 2008.

Mori, I., Nishikawa, M., Quan, H., and Iwasaka, Y.: Regional characteristics of Chinese atmospheric aerosols in terms of the stable carbon isotope ratios. In: Abstract of annual meeting of Japan Society for Atmospheric Environment (in Japanese), 40, p. 419, 1999.

Nielsen, T.: The decay of benzo[a]pyrene and cyclopenteno[cd]pyrene in the atmosphere, Atmos. Environ., 22, 22492254, 1988.

Okuda, T., Okamoto, K., Tanaka, S., Shen, Z. X., Han, Y. M., and Huo, Z. Q.: Measurement and source identification of polycyclic aromatic hydrocarbons (PAHs) in the aerosol in Xi'an, China, by using automated column chromatography and applying positive matrix factorization (PMF), Sci. Total Environ., 408, 1909-1914, 2010.

Omar, N. Y. M. J., Abas, M. R. B., Ketuly, K. A., and Tahir, N. $\mathrm{M}$.: Concentrations of PAHs in atmospheric particles $\left(\mathrm{PM}_{10}\right)$ and roadside soil particles collected in Kuala Lumpur, Malaysia, Atmos. Environ., 36, 247-254, 2002.

Peltzer, E. T. and Gagosian, R. B.: Organic geochemistry of aerosols over the Pacific Ocean, in: Chemical Oceanography, edited by: Riley, J. P. and Chester, R., Academic Press, London, 10, 281338, 1989.

Ramana, M. V., Ramanathan, V., Feng, Y., Yoon, S.-C., Kim, S.-W., Carmichael, G. R., and Schauer, J. J.: Warming influenced by the ratio of black carbon to sulphate and the black-carbon source, Nat. Geosci., 3, 542-545, 2010.

Reid, J. S., Eck, T. F., Christopher, S. A., Koppmann, R., Dubovik, O., Eleuterio, D. P., Holben, B. N., Reid, E. A., and Zhang, J.: A review of biomass burning emissions part III: intensive optical properties of biomass burning particles, Atmos. Chem. Phys., 5, 827-849, doi:10.5194/acp-5-827-2005, 2005.

Santos, F. J. and Galceran, M. T.: Review: Modern developments in gas chromatography-mass spectrometry based environmental analysis, J. Chromatogr. A., 1000, 125-151, 2003.

Seinfeld, J. H. and Pankow, J. F.: Organic atmospheric particulate material, Annu. Rev. Phys. Chem., 54, 121-140, 2003.

Shen, Z. X., Cao, J. J., Arimoto, R., Zhang, R. J., Jie, D. M., Liu, S. X., and Zhu, C. S.: Chemical composition and source characterization of spring aerosol over Horqinsandland in northeastern China, J. Geophys. Res., 112, D14315, doi:10.1029/2006JD007991, 2007.

Shen, Z. X., Cao, J. J., Tong, Z., Liu, S. X., Lingala Siva Sankara Reddy, Han, Y. M., Zhang, T., and Zhou, J.: Chemical characteristics of submicron particles in winter in Xi' an, Aerosol Air Qual. Res., 9, 80-93, 2009.

Sicre, M. A., Marty, J. C., Saliot, A., Aparicio, X., Grimalt, J., and Albaiges, J.: Aliphatic and aromatic hydrocarbons in different sized aerosols over the Mediterranean Sea Occurrence and origin, Atmos. Environ., 21, 2247-2259, 1987.

Simoneit, B. R. T.: Organic matter of the troposphere: Characterization and sources of petroleum and pyrogenic residues in aerosols over the Western United States, Atmos. Environ., 18, 51-67, 1984.
Simoneit, B. R. T.: Application of molecular marker analysis to vehicular exhaust for source reconciliations, Int. J. Anal. Chem., 22, 203-233, 1985.

Turekian, V. C., Macko, S., Ballentine, D., Swap, R. J., and Garstang, M.: Causes of bulk carbon and nitrogen isotopic fractionations in the products of vegetation burns: laboratory studies, Chem. Geol., 152, 181-192, 1998.

Turpin, B. J. and Huntzicker, J. J.: Identification of secondary aerosol episodes and quantification of primary and secondary organic aerosol concentrations during SCAQS. Atmos. Environ., 29, 3527-3544, 1995.

Turpin, B. J. and Lim, H. J.: Species contributions to $\mathrm{PM}_{2.5}$ mass concentrations: revisiting common assumptions for estimating organic mass, Aerosol Sci. Technol., 35, 602-610, 2001.

Turpin, B. J., Saxena, P., and Andrews, E.: Measuring and simulating particulate organics in the atmosphere: Problems and prospects, Atmos. Environ., 34, 2983-3013, 2000.

USEPA, Compendium of methods for the determination of toxic organic compounds in ambient air, Method TO-13A: Determination of polycyclic aromatic hydrocarbons (PAHs) in ambient air using gas chromatography/mass spectrometry (GC-MS), Washington, DC, 1997.

vanDrooge, B. L. Nikolova, I., and Pérez Ballesta, P.: Thermal desorption gas chromatography mass spectrometry as an enhanced method for the quantification of polycyclic aromatic hydrocarbons from ambient air particulate matter, J. Chromatogr. A., 1216, 4030-4039, 2009.

Wang, Y., Zhuang, G., Sun, Y, and An, Z.: The variation of characteristics and formation mechanisms of aerosols in dust, haze, and clear days in Beijing, Atmos. Environ., 40, 6579-6591, 2006.

Wang, G. H., Kawamura, K., Lee, S. C., Ho, K. F., and Cao, J. J.: Molecular, seasonal, and spatial distributions of organic aerosols from fourteen Chinese cities, Environ. Sci. Technol., 40, 46194625, 2006.

Watson, J. G., Chow, J. C., and Houck, J. E.: PM$_{2.5}$ chemical source profiles for vehicle exhaust, vegetative burning, geological material, and coal burning in northwestern Colorado during 1995, Chemosphere, 43, 1141-1151, 2001.

Widory, D.: Combustibles, fuels and their combustion products: a view through carbon isotopes. Combust.Theor.Model 10, 831841, 2006.

Widory, D., Roy, S., Le Moullec, Y., Goupil, G., Cocherie, A., and Guerrot, C.: The origin of atmospheric particles in Paris: a view through carbon and lead isotopes, Atmos. Environ., 38, 953-961, 2004.

Yang, F., He, K., Ye, B., Chen, X., Cha, L., Cadle, S. H., Chan, T., and Mulawa, P. A.: One-year record of organic and elemental carbon in fine particles in downtown Beijing and Shanghai, Atmos. Chem. Phys., 5, 1449-1457, doi:10.5194/acp-5-1449-2005, 2005.

Yao, X., Chan, C. K., Fang, M., Cadle, S., Chan, T., Mulawa, P., He, $\mathrm{K}$., and Ye, B.: The water-soluble ionic composition of $\mathrm{PM}_{2.5}$ in Shanghai and Beijing, China, Atmos. Environ., 36, 4223-4234, 2002.

Ye, B. M., Ji, X. L., Yang, H. Z., Yao, X. H., Chan, C. K., Cadle, S. H., Chan, T., and Mulaw, P. A.: Concentration and chemical composition of $\mathrm{PM}_{2.5}$ in Shanghai for a 1-year period, Atmos. Environ., 37, 499-510, 2003. 
Zeng, T. and Wang, Y. H.: Nationwide summer peaks of OC/EC ratios in the contiguous United States, Atmos. Environ., 45, 578$586,2011$.

Zhang, M. G., Han, Z. W., and Zhu, L. Y.: Simulation of atmospheric aerosols in East Asia using modeling system RAMSCMAQ: model evaluation, China Particuol., 5, 321-327, 2007.

Zhang, R. J., Ho, K. F., Cao, J. J., Han, Z. W., Zhang, M. G., Cheng, Y., and Lee, S. C.: Organic carbon and elemental carbon associated with $\mathrm{PM}_{10}$ in Beijing during spring time, J. Hazard Mater., 172, 970-977, 2009.

Zhao, J. P., Zhang, F. W., Chen, J. S., and Xu, Y.: Characterization of polycyclic aromatic hydrocarbons and gas/particle partitioning in a coastal city, Xiamen, Southeast China, J. Environ. Sci., 22, 1014-1022, 2010.
Zheng, M. and Fang M.: Particle-associated polycyclic aromatic hydrocarbons in the atmosphere of Hong Kong, Water Air Soil Pollut., 117, 175-189, 2000.

Zheng, M., Fang, M., Wang, F., and To, K. L.: Characterization of the solvent extractable organic compounds in $\mathrm{PM}_{2.5}$ aerosols in Hong Kong, Atmos. Environ., 342, 691-702, 2000.

Zhu, C. S., Chen, S. C., Cao, J. J., Tsai, C. J., Chou, C. C. K., Liu, S. C., and Roam, G. D.: Characterization of carbon fractions for atmospheric fine particles and nanoparticles in a highway tunnel, Atmos. Environ., 44, 2668-2673, 2010. 